\title{
'n Evaluering van die welstand onder werknemers van 'n mediesefondsmaatskappy in Suid-Afrika
}

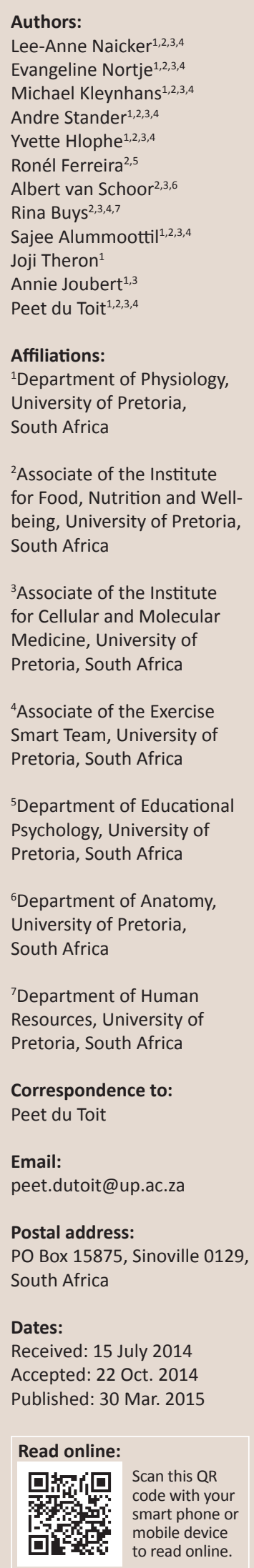

Huidige navorsing op die gebied van welstand in die werkplek is gefragmenteer en vereis 'n holistiese, geïntegreerde en stelselmatige begrip van werknemerwelstand sodat gesondheiden welstandsorg doeltreffend bestuur kan word. Die toenemende las van nie-oordraagbare toestande in Suid-Afrika beklemtoon die noodsaaklikheid van voorkomingstrategieë soos welstandprogramme. Die werkomgewing bied 'n ideale plek, aangesien 'n groot deel van die bevolking geteiken word, insluitende diegene wie se lewenstyl verbeter moet word. Hierdie studie is dus daarop gemik om verskeie gesondheid- en welstandkomponente onder werknemers van 'n mediesefondsmaatskappy te evalueer in 'n poging om risikogebiede te identifiseer wat verdere ingryping vereis. Die deelnemers het bestaan uit 140 werknemers van ' $n$ mediesefondsmaatskappy wat ten minste $40 \mathrm{~h}$ per week werk. Hulle is onderwerp aan ' $n$ welstandassesseringsbattery bestaande uit antropometrieke, gesondheidverwante en fisieke kapasiteitmetings. Die resultate toon dat ingryping nodig is betreffende alkohol- en dwelmgebruik, dieetgewoontes, hartgesondheid, liggaamsamestelling, spieruithouvermoë, kardiorespiratoriese uithouvermoë en individuele persepsies van die maatskappy. Dié studie het resultate opgelewer wat die bevindings van baie vorige navorsing op hierdie gebied staaf. Die trefwydte van welstandprogramme op die Suid-Afrikaanse bevolking is egter beperk. Die sukses van welstandprogramme wat fisieke aktiwiteit beklemtoon, is goed gedokumenteer in hoë-inkomstelande, met bewys van die ekonomiese voordele en opbrengs op belegging. Gevolglik word daar aangevoer dat die toepassing van welstandprogramme 'n positiewe uitwerking op die Suid-Afrikaanse werkmag sal hê.

An evaluation of the state of wellness amongst medical aid company employees in South Africa. Current research in the area of wellness in the workplace is fragmented and requires a holistic, integrated and systemic understanding of employee wellness in order for health and wellness care to be effectively managed. The growing burden of noncommunicable conditions in South Africa highlights the necessity for prevention strategies such as wellness programmes to be implemented. The workplace provides an ideal setting as a large proportion of the population will be targeted, including those who require lifestyle improvement. Therefore this study sought to evaluate various health and wellness components among employees of a medical aid company in an attempt to identify risk areas which require further intervention. Participants were 140 employees of a medical aid company who work a minimum of $40 \mathrm{~h}$ per week and who were subjected to a wellness assessment battery, consisting of anthropometrical, health-related and physical capacity measurements. The results indicate that intervention is required in terms of alcohol and drug usage, dietary habits, heart health, body composition, muscular endurance, cardiorespiratory endurance, and individual perceptions towards the company. This study produced results which corroborate the findings of a great deal of previous research in this field. However, the scope for applying wellness programmes to the South African population is limited. The success of wellness programmes which emphasise physical activity has been well documented in high-income countries, with evidence of economic benefits and return on investment. And so it is proposed that implementation of wellness programmes will have a positive effect on the South African workforce.

\section{Inleiding}

Daar was die afgelope jare 'n dramatiese verskuiwing in die welstandparadigma, van 'n patogeniese na 'n holistiese benadering wat geestelike, fisieke en sosiale komponente behels. Gevolglik is verskeie welstandmodelle ontwikkel, soos die Wheel of Wellness (Witmer \& Sweeney

How to cite this article: Naicker, L-A., Nortje, E., Kleynhans, M., Stander, A., Hlophe, Y., Ferreira, R. et al., 2015, " $n$ Evaluering van die welstand onder werknemers van 'n mediesefondsmaatskappy in Suid-Afrika', Suid-Afrikaanse Tydskrif vir Natuurwetenskap en Tegnologie 34(1), Art. \#1213, 7 pages. http://dx.doi.org/10.4102/satnt.v34i1.1213

Copyright: @ 2015. The Authors. Licensee: AOSIS OpenJournals. This work is licensed under the Creative Commons Attribution License. 
1992), die Indivisible Self: An Evidence-Based Model of Wellness (Myers \& Sweeney 2005) en die Perceived Wellness Model (Adams, Bezner \& Steinhardt 1997). Dit behels die gewysigde definisie van welstand soos voorgestel deur Hurley en Schlaadt (1992), wat die verantwoordelikheid vir algemene welstand op die individu plaas deur lewenstylgedrag wat gesondheid bevorder. Dit verseker dat die onus op die individu is om 'n holistiese gevoel van welstand te verkry deur lewenstylmodifikasies.

Nie-oordraagbare siektes in Suid-Afrika deel 'n aantal modifiseerbare faktore wat insluit, maar nie beperk is nie tot, hipertensie, tabakgebruik, hipercholesterolemie, obesiteit en sedentêre gedrag (Van Zyl et al. 2012). Voorts het Norman et al. (2007) 'n vergelykende risikobeoordeling gedoen van sterfgevalleinSuid-Afrika wat aan geselekteerde risikofaktore toegeskryf word. In dié studie was hoë bloeddruk in die tweede posisie, naas seksueel oordraagbare siektes, tabakgebruik derde, alkoholbenadeling vierde, verhoogde liggaamsmassa-indeks (LMI) vyfde, hipercholesterolemie sewende en fisieke onaktiwiteit negende.

Dit is belangrik om daarop te let dat, benewens individuele verantwoordelikheid en genetiese en omgewingsfaktore wat beheer kan word om 'n gevoel van welstand te verkry, daar ook faktore is wat buite die individu se beheer is. Dit sluit in die fisieke en psigososiale dimensies van die werkplek, wat insluit die organisasie van werk, bestuurspraktyke en werkvereistes (Shain \& Kramer 2004). Om hierdie rede bevoordeel welstandingryping in die werkplek vermoedelik die organisasie as geheel, asook die individu. Navorsing toon dat daar 'n opbrengs op belegging van hierdie programme is (Arena et al. 2013), asook hoër produktiwiteit (Proper et al. 2002), wat lei tot tevredenheid by die werknemers en wins vir die organisasie.

Die begrip 'welstand' word in die Suid-Afrikaanse konteks nie goed verstaan nie, en dit lei tot tekortkominge in huidige welstandprogram-inisiatiewe vir werknemers. Els, Pienaar en Sieberhagen (2011) het 'n studie oor werknemerwelstand in Suid-Afrika gedoen waarin hulle gekonsentreer het op die perspektiewe van onderskeidelik werkgewer, diensverskaffer en vakbonde. Hulle het bevind dat daar na welstand verwys word as gesondheid, beroepsgesondheid en veiligheid, en nakoming van wetsvereistes, naamlik die Wet op Beroepsgesondheid en Veiligheid (wet nr. 85 van 1993) en ander riglyne (Els et al. 2011). Voorts is daar bevind dat die deelnemende organisasies nie 'n basislynmeting het waarmee die doeltreffendheid van hul welstandprogramme vir werknemers vergelyk kan word nie. Dit toon die noodsaaklikheid aan van siftingsmetings en die monitering van werknemerwelstand sodat werkgewers hul welstandprogramme doeltreffend kan bestuur.

Een metode om welstand in die werkplek te assesseer is Gesondheidsrisiko-assessering (GRA), of Health Risk Assessment (HRA), wat inligting vaslê rakende demografiese eienskappe, lewenstyl (soos oefening, rook, alkoholinname en dieet), persoonlike en familiale mediese geskiedenis, fisiologiese data (soos LMI, bloeddruk en cholesterol), asook houdings en bereidheid om gedrag te verander ten einde gesondheid te verbeter (Arena et al. 2013). GRA's bied ' $n$ assessering van risiko vir gesondheid en bewustheid van werknemers se modifiseerbare risikofaktore, en doen strategieë aan die hand om gesondheidsgedrag te modifiseer (Arena et al. 2013). GRA's berus egter op selfvermelde inligting, wat die gehalte en betroubaarheid van die inligting in ' $n$ bepaalde perspektief stel betreffende die sydigheid in terme van onthou, reaksie en sosiale wenslikheid (Birdee $e t$ al. 2013). Hoewel GRA's hoërisiko-individue kan identifiseer, gepaste behandeling kan aandui en 'n geleentheid kan bied om hoërisiko-werknemers aan te moedig om lewenstylveranderinge aan te bring ten einde die risiko van nie-oordraagbare toestande te verminder, verwaarloos dit ook 'n belangrike aspek van welstand wat die grondslag van die meeste lewenstylverwante siektes bied, naamlik fisieke welstand (Arena et al. 2013).

Fisieke welstand word meestal met gesond wees geassosieer en behels die handhawing van 'n gesonde liggaam deur toereikende dieet, fisiek aktief te wees, nadelige gewoontes te vermy, ingeligte en verantwoordelike besluite oor gesondheid te neem en aan siektevoorkomende aktiwiteite deel te neem (Edlin, Golanty \& Brown 2000). Al-naddaf en Dabayebeh (2007) het bevind dat dit die afname in gereelde fisieke aktiwiteit is, en nie 'n positiewe energiebalans nie, wat gelei het tot die stygende voorkoms van obesiteit, en dít beklemtoon die noodsaaklikheid van die nakoming van aanbevelings oor fisieke aktiwiteit. Die handhawing van ' $n$ fisiek aktiewe lewenstyl moet een van die sleutelkomponente van welstandinisiatiewe in die werkplek wees. Daar is aangetoon dat 'n sedentêre lewenstyl 'n mens nie net vatbaar vir hipokinetiese siektes maak nie (Labuschagne, Strydom \& Wilders 2011), maar ook vir kardiovaskulêre sterftes en sterftes aan alle ander oorsake (Arena et al. 2013).

Vanweë die baie tyd wat by die werkplek deurgebring word, word dit beskou as 'n doeltreffende plek vir strategieë wat welstand bevorder. Die grondslag van hierdie beweegrede is dat ' $n$ groot persentasie van die bevolking geteiken sal word, insluitende diegene wat lewenstylverbetering nodig het (Rongen et al. 2014). Om welstandingryping in die werkplek te ontwerp, is dit egter nodig om te bepaal hoe werknemers gesondheid en welstand beskou en om toets- en sifmaatreëls in te stel ten einde werknemers se gesondheiden welstandbehoeftes te bepaal. Dié studie is dus daarop gemik om verskeie gesondheid- en welstandkomponente onder werknemers van 'n mediesefondsmaatskappy te evalueer in 'n poging om risikogebiede te identifiseer wat verdere ingryping vereis.

\section{Metode}

Werknemers van 'n mediesefondsmaatskappy in SuidAfrika wat ten minste $40 \mathrm{~h}$ per week werk, is genooi om aan die studie deel te neem. ' $n$ Inleidende vergadering is gehou, waartydens die doel en prosedures van die studie 
verduidelik is. Deelnemers het geleentheid gekry om vrae te stel en kwellings rakende die studie te opper. Altesaam 140 werknemers tussen die ouderdomme 18 en 50 het ingewillig om aan die studie deel te neem en het vorms voltooi om hul ingeligte toestemming te gee.

Die welstandassesseringsbattery het bestaan uit antropometrieke, gesondheidsverwante en fisieke kapasiteitmetings.

Liggaamsamestelling is gemeet deur middel van 'n bioimpedansie-ontleder, die Bodystat ${ }^{\circledR} 1500$ (Bodystat, Eiland Man, VK). Deelnemers is versoek om op 'n mat op hul rug te lê in 'n anatomiese posisie terwyl vier elektrodes geplaas is - twee aan die regterhand (een aan die kneukel van die wysvinger en een mediaal tot die ulnêre kop) en twee aan die regtervoet (een aan die groottoon en een aan die enkel tussen mediale en laterale malleoli) - en 'n opname is 5 min lank gemaak (Thomas et al. 1998).

Hartgesondheid is gemeet deur die kardiale stresindeks, 'n afleiding van hartklopveranderlikheid, te bereken met behulp van die Viport (Energy-Lab Technologies GmbH). Die Viport meet die kardiale stresindeks deur 'n algoritme wat hartklop, hartritme, QRS-duur en die standaardafwyking tussen R-Rintervalle (RRSD) behels (Aghamohamadi et al. 2010; EnergyLab Technologies GmbH 2010; Energy-Lab Technologies $\mathrm{GmbH}$ 2014). Terwyl die deelnemers in ' $n$ sittende posisie bly en 'n regop houding handhaaf, is die boonste twee elektrodes van die Viport op die eerste interkostale ruimte aan die linkerkant van die borskas geplaas. Voordat die Viport op die deelnemers geplaas is, moes die elektrodes met geleidingsjel bevog word. Daar is sorg geneem om te verseker dat al drie elektrodes in kontak met vel is en dat geen metaalvoorwerpe (soos juweliersware) met elektrodeseine inmeng nie. Nadat alles korrek op die deelnemer geplaas is, is die Viport aangeskakel. Die deelnemers is gelas om 2 min lank natuurlik asem te haal en geen skielike bewegings te maak of te praat nie terwyl die lesing geneem word.

Spieruithouvermoë is bepaal deur die deelnemer opsitte te laat doen (Beam \& Adams 2010; Mackenzie 2005). Al die deelnemers moes in die beginposisie op hul rug op 'n mat op die vloer lê met knieë gebuig en die dorsum van die voete op die vloer en arms oor die bors gevou. Hulle moes hulle dan tot ' $n 90^{\circ}$-posisie oplig en na die beginposisie terugkeer. Die getal opsitte wat in $1 \mathrm{~min}$ gedoen is, is aangeteken.

Kardiorespiratoriese uithouvermoë is gemeet met behulp van die traptoets van 3 min (Beam \& Adams 2010; Mackenzie 2005). 'n Bankie van $40 \mathrm{~cm}$ hoog is gebruik. Elke deelnemer moes op en af van die bankie klim teen 'n tempo van 24 trappe per minuut, soos deur 'n metronoom gestel, vir 'n tydperk van $3 \mathrm{~min}$. Onmiddellik na die $3 \mathrm{~min}$ moes die deelnemer gaan sit en die karotispols geneem word. Vyf sekondes na voltooiing van die trappe is die polsslag $60 \mathrm{~s}$ lank getel, en dit is aangeteken.

Bloeddruk is gemeet in ' $n$ sittende posisie met' $n$ handbediende sfigmomanometer (Beam \& Adams 2010), en die finale lesing is aangeteken as sistoliese druk/diastoliese druk in millimeter kwik (mm Hg).

Bykomende besonderhede soos mediese geskiedenis, lewenstylfaktore, persepsies teenoor die maatskappy, en persoonlike en familiegeskiedenis is deur middel van selftoegediende vraelyste verkry (Prentice 1999).

\section{Etiekvereistes en voorwaardes}

Geen spesifieke wetgewende nakomingsvereistes was van toepassing nie. Die kernnavorsingspan en alle nagraadse studente betrokke, het voldoen aan die vereistes van etiese riglyne wat betref ingeligte toestemming, vertroulikheid en anonimiteit, vrywillige deelname en beskerming teen gevaar. In die konteks van kwesbaarheid is spesiale versigting gebruik om enige potensiële skade aan deelnemers te identifiseer. Verder is deelnemers ook na beradingsdienste verwys indien nodig.

Die nodige toestemming om navorsing te doen is van die maatskappy verkry. Etiese goedkeuring is van die Universiteit van Pretoria en ingeligte toestemming van die deelnemers verkry.

\section{Stoor van data}

Rou en ontlede data sal vir 'n tydperk van 15 jaar in 'n veilige plek by die Universiteit van Pretoria gestoor word. Data sal opgespoor word soos dit vir voortgesette studies en ontleding benodig word. Bevindinge sal versprei word op nasionale en internasionale forums, by konferensies en in geskrewe formaat in die vorm van artikels en ander publikasies.

\section{Resultate}

Die bevindings is as ' $n$ risikoprofiel opgesom en het die persentasie werknemers getoon wat as positief op die gebiede van welstand beskou is en dit is vergelyk met dié wat ingryping nodig het, spesifiek diegene wat as gebrekkig op genoemde gebiede van welstand beskou is (Tabel 1).

Lewenstylgewoontes wat as hoë risiko of ongesond beskou is, sluit in daaglikse rook of rook by geleentheid (Laaksonen, Práttalä \& Karisto 2001), alkoholgebruik van meer as agt eenhede per week vir mans en meer as vyf eenhede per week vir vroue (Laaksonen, Práttalä \& Karisto 2001), en dieetgewoontes, insluitende twee of drie ongesonde keuses uit die items van die somindeks bestaande uit die volgende komponente: eet vars groente minder as drie keer week, eet botter op brood of drink volroommelk, eet vyf of meer snye brood per dag (Laaksonen, Práttalä \& Karisto 2001). Daar is egter verskeie voedingsriglyne in sirkulasie wat teenstrydige inligting bied (Caldwell \& Huitt 2004). Desondanks word dit egter algemeen aanvaar dat voedingstatus afhanklik is van energievereiste, liggaamsgrootte en fisieke aktiwiteit (Westerterp 2010). Optimale dieetgewoontes vir gesondheid en welsyn vereis dat koolhidrate, vette, proteïene, vitamiene, minerale en ander mikrovoedingstowwe in voldoende en gebalanseerde hoeveelhede aan die 
TABEL 1: Voorkoms van ongesonde, hoërisikogedrag, aggregasie en verspreiding van risikoprofielveranderlikes volgens ingrypingsbehoefte.

\begin{tabular}{|c|c|c|c|}
\hline Risikoprofiel & Veranderlikes & Hoë risiko (ingryping nodig) (\%) & Lae risiko (ingryping nie nodig nie) (\%) \\
\hline Mediese geskiedenis & - & Kyk Tabel 2 & Kyk Tabel 2 \\
\hline Lewenstylgewoontes & - & 53 & 47 \\
\hline Tabakgebruik & - & 32 & 68 \\
\hline Alkohol- en dwelmgebruik & - & 80 & 20 \\
\hline Dieetgewoontes & - & 55 & 44 \\
\hline Seksuele lewenstyl & - & 30 & 70 \\
\hline Houding & - & 0 & 100 \\
\hline Persepsies & - & Kyk Tabel 3 & Kyk Tabel 3 \\
\hline \multirow[t]{2}{*}{ Bloeddruk } & Sistolies & 36 & 64 \\
\hline & Diastolies & 27 & 73 \\
\hline \multirow[t]{2}{*}{ Liggaamsamestelling } & Manlik & 72 & 28 \\
\hline & Vroulik & 92 & 8 \\
\hline Spieruithouvermoë & Manlik & 94 & 6 \\
\hline \multirow[t]{2}{*}{ Kardiorespiratoriese uithouvermoë } & Manlik & 80 & 20 \\
\hline & Vroulik & 48 & 52 \\
\hline
\end{tabular}

liggaam voorsien word (McArdle, Katch \& Katch 2010). Hierdie makro- en mikrovoedingstowwe is noodsaaklik vir normale orgaanontwikkeling en funksionering; vir selvoortplanting, groei en onderhoud; vir hoë energie- en werkdoeltreffendheid; vir weerstand teen infeksie en siekte; en vir die vermoë om van liggaamlike skade of besering te herstel (McArdle et al. 2010). Geen voedingstof werk alleen nie; elkeen is afhanklik van die teenwoordigheid van ander vir optimale effekte (McArdle et al. 2010).

'n Kardiale stresindeks van laer as 25 is beskou as lae risiko (Energy-Lab Technologies GmbH 2014), of goed vir hartgesondheid. Hoërisiko-resultate in die biometriese ontleding behels liggaamsvetpersentasie bo $30 \%$ vir vroue en bo $20 \%$ vir mans (Jeukendrup \& Gleeson 2009), sistoliese bloeddruk hoër as $139 \mathrm{~mm} \mathrm{Hg}$ en diastoliese bloeddruk hoër as $89 \mathrm{~mm} \mathrm{Hg}$ (Centers for Disease Control and Prevention 2011), kardiorespiratoriese uithouvermoë bokant 36 slae per 15 sekondes (American College of Sports Medicine 2010), en spieruithouvermoë van minder as 24 opsitte per minuut (American College of Sports Medicine 2010).

Tabel 1 toon 'n opvallende persentasie alkohol- en dwelmgebruik, asook 'n noemenswaardige afname in hartgesondheid en eetgewoontes. Biometriese ontleding toon 'n hoë persentasie van die bevolking met swak liggaamsamestelling, spieruithouvermoë en kardiorespiratoriese uithouvermoë.

\section{Mediese geskiedenis}

Persoonlike en familiegeskiedenis is aangeteken om risikogebiede vir die verkryging van 'n gevoel van welstand te bepaal. Dit is ook nodig om probleemgebiede te identifiseer ten einde 'n welstandprogram te ontwerp en te implementeer, aangesien dit voorsiening maak vir voorsorgmaatreëls om komplikasies te voorkom en verdere risiko's te verminder. Tabel 2 toon 'n merkbare persentasie werknemers wat gediagnoseer is met chroniese toestande soos pyn in die laer rug, hipertensie, hipercholesterolemie en asma. Verder is 'n familiegeskiedenis van chroniese toestande, veral hipercholesterolemie, hipertensie en hartsiekte, 'n sterk aanduiding van 'n genetiese predisposisie vir die genoemde toestande, wat dus beteken dat werknemers met dié geskiedenis 'n groter risiko het.

\section{Persepsies}

Tabel 3 toon die werknemers se persepsie van hul werkplek. Dit is gebruik om die vlakke te bepaal van werkstres en werkbevrediging wat 'n impak het op produktiwiteit, moraal en uiteindelik gesondheid en welstand. Daar is getoon dat hoewel 'n groot persentasie werknemers vertroue het in hul dienste of produkte, hulle ontevrede met werktoestande is. Deelnemers het egter gevoel hulle kan persoonlike sake met

TABEL 2: Persentasie van deelnemers met chroniese toestande, asook 'n geskiedenis van chroniese lewenstylverwante toestande.

\begin{tabular}{lll}
\hline Geskiedenis & Toestande & \% van personeel \\
\hline Persoonlike geskiedenis & Gereelde medikasie & 13.79 \\
& Pyn in die laer rug & 44.83 \\
& Hipertensie & 20.69 \\
& Asma & 20.69 \\
& Hoofpyn & 13.79 \\
& Krampe in bene & 17.24 \\
Artritis & 3.45 \\
Stywe gewrigte & 3.45 \\
Obesiteit & 10.34 \\
& Kardiale probleme of & 13.79 \\
hartsiekte & \\
Cholesterol & 17.24 \\
& Borspyn terwyl gestap word & 10.34 \\
& Nierprobleme & 3.45 \\
& Duiseligheid & 3.45 \\
Breuke & 3.45 \\
\hline Familiegeskiedenis & Cholesterol & 34.48 \\
& Hartsiekte & 13.79 \\
Diabetes & 10.34 \\
Hipertensie & 27.59 \\
Obesiteit & 3.45 \\
Beroerte & 10.34 \\
\hline
\end{tabular}


TABEL 3: Persepsies van werknemer oor organisasie.

\begin{tabular}{ll}
\hline Persepsies & Maatskappytelling (\%) \\
\hline Persoonlik ongelukkig by die werk & 37 \\
Voel die bestuur is soms onredelik & 13 \\
Voel ander word meer bevoordeel & 21 \\
$\begin{array}{l}\text { Voel hulle kan persoonlike probleme met die bestuur } \\
\text { bespreek }\end{array}$ & 82 \\
Voel ander personeellede is onredelik teenoor hulle & 51 \\
Voel opleiding is ontoereikend & 68 \\
\hline Het vertroue in hul dienste en produkte & 77 \\
\hline Ongelukkig met werktoestande & 72 \\
\hline
\end{tabular}

die bestuur bespreek, wat 'n positiewe omgewing verskaf en 'n gevoel van welstand moontlik maak.

\section{Bespreking}

Die vernaamste resultaat van hierdie evaluasie van welstand onder werknemers van 'n mediesefondsmaatskappy toon die behoefte aan werkplekingryping wat verskeie aspekte van welstand behels soos beskryf deur Edlin, Golanty en Brown (2000). Dié studie het resultate opgelewer wat die bevindings van baie vorige navorsing op hierdie gebied staaf (Christensen et al. 2011; Kerr \& Vos 1993). Die trefwydte van welstandprogramme in die Suid-Afrikaanse bevolking is egter beperk.

Resultate van hierdie studie toon dat $80 \%$ van die 140 werknemers ingryping nodig het met betrekking tot alkoholen dwelmgebruik en 55\% vir eetgewoontes. Navorsing met betrekking tot alkoholmisbruik beraam dat die verbruik van alkohol in Suid-Afrika tussen $9 \mathrm{~L}$ en $10 \mathrm{~L}$ per kapita is, met selfs hoër vlakke indien brouselalkohol ingesluit word (Seggie 2012). Statistiek soos dié plaas Suid-Afrika as een van die lande met die hoogste alkoholverbruik per kapita in die wêreld, en verbruik gaan voort om te styg.

Werknemers met hoë alkoholgebruik, 'n hoë kardiale stresindeks, swak liggaamsamestelling en swak eetgewoontes is vatbaarder vir toestande soos kardiovaskulêre siekte, tipe 2 diabetes mellitus, beroerte en iskemiese hartsiekte (Birdee et al. 2013; Norman et al. 2007). Blair, Cheng en Scott Holder (2001) het getoon dat daar 'n dosis-responsverhouding is tussen fisieke aktiwiteit en gesondheid wat dui op langlewendheid en 'n laer risiko vir nie-oordraagbare toestande. Verder is 'n sterk omgekeerde verhouding tussen kardiorespiratoriese fiksheid en sterftes getoon.

Shain en Kramer (2004) het die faktore aangetoon wat welstand in die werkplek beïnvloed deur gesondheid en produktiwiteit. Daar is bevind dat persoonlike gesondheidspraktyke welstand en produktiwiteit direk kan beïnloed deur dinge soos rook en groter inname van kafeïen (Masley et al. 2008), en indirek deur verwaarlosing wat tot die ontwikkeling van siektes (Cox, Shephard \& Corey 1981), en uiteindelik tot afwesigheid kan lei. Persoonlike hulpbronne soos gehardheid, selfdoeltreffendheid, veerkrag en sosiale steun fungeer as bemiddelaars tussen die fisieke en psigososiale dimensies van werkplekwelstand en gesondheidspraktyke (Shain \& Kramer 2004); en kan vergoed vir die negatiewe gevolge van werkorganisasie vir gesondheidspraktyke, maar kan ook getroef word indien die negatiewe gevolge sou voortduur. Organisasie van werk kan welstand direk beïnvloed deur die ontwerp van die werkstelsel en indirek deur bestuurspraktyke wat negatiewe emosionele toestande veroorsaak wat weer strydig is met produktiwiteit, en ook tot fisieke siekteprosesse kan bydra (Shain \& Kramer 2004).

'n Aansienlike persentasie van die deelnemers aan hierdie studie is gediagnoseer met chroniese toestande soos pyn in die laer rug, hipertensie, hipercholesterolemie en asma, en het 'n familiegeskiedenis van toestande, veral hipercholesterolemie, hipertensie en hartsiekte. Die voorkoms van hierdie toestande, asook familiegeskiedenis, dui op 'n sterk genetiese korrelasie. 'n Moontlike verklaring kan wees dat die breë bevolking blootgestel is aan 'n sedentêre omgewing, wat lei tot wanaanpassing van die menslike genoom, en dit lei dan tot abnormale geenuitdrukking en uiteindelik manifestering as nie-oordraagbare toestande (Booth, Chakravarthy \& Spangenburg 2002). Dit word verder gesteun deur Gerber en Crews (1999), wat aanvoer dat blootstelling van allele aan 'n sedentêre omgewing, asook diëte ryk aan vet en suiker, maar arm aan vesel, draers blootstel aan die risiko van chroniese toestande en verkorte lewensduur.

'n Ewekansig beheerde proefneming deur Christensen et al. (2011) het die uitwerking van ' $n$ lewenstylingryping by gesondheidsorgwerkers gedurende werkure probeer evalueer. 'n Beduidende verbetering van LMI, liggaamsvetpersentasie, middellyfomtrek, aërobiese fiksheid en bloeddruk is aangetoon. Die ingryping het egter nie 'n beduidende uitwerking op spier- en skeletpyn, maksimale suurstofinname en spiersterkte gehad nie. Dit is belangrik om daarop te let dat daar 'n hoë koers van volharding in hierdie studie was, en net sewe van die 98 deelnemers het uitgesak. Hoewel die behoefte aan fisieke welstandingryping geïdentifiseer is en die voordele bekend is, is dit nodig om aandag te gee aan versperrings en fasiliteerders vir deelname aan 'n werkplekwelstandprogram. Versperrings wat geïdentifiseer is, sluit in gebrek aan tyd, gebrek aan motivering, gebrek aan hulpbronne, ongunstige werkskedule en werknemers wat reeds gesond voel (Rongen et al. 2014; Wierenga et al. 2013). Fasiliteerders wat geïdentifiseer is, sluit in bereidheid om jou lewenstyl te verander, werkplekkultuur en sterk steun deur die bestuur (Rongen et al. 2014; Wierenga et al. 2013).

'n Studie wat onder werknemers aan 'n universiteit in die Verenigde State van Amerika gedoen is, toon dat werknemers selfs met 'n gevestigde welstandprogram steeds lae vlakke van fisieke aktiwiteit gemeld het, met 'n groter voorkoms van obesiteit, kardiovaskulêre toestande, meer siekteverlof en swak tot matige gesondheidstatus (Birdee et al. 2013). Die werknemers het egter die voorneme uitgespreek om aan welstandinisiatiewe deel te neem. Dit word gestaaf deur 'n stelselmatige oorsig oor die prosesevaluasie van programme wat werkplekgesondheid bevorder deur Wierenga et al. (2013), wat die strydigheid tussen implementering en 
doeltreffendheid toon. Boonop is hierdie strydigheid toegeskryf aan die gebrek aan kwantifiseerbare data op dié navorsingsgebied, aangesien die fokus op anekdotiese bewyse geval het. Gevolglik word daar voorgestel dat 'n basislyn van data vasgestel moet word voordat 'n welstandprogram vir werknemers geïmplementeer word sodat die doeltreffendheid van dié programme in opvolgstappe gekwantifiseer kan word.

Die bevindings van hierdie studie toon die behoefte aan die implementering van welstandprogramme in die werkplek in Suid-Afrika. Daar is aangetoon dat 'n gesonde lewenstyl, asook matige verbeterings in die fiksheid van 'n werknemer kan lei tot groter produktiwiteit (Rongen et al. 2014), minder afwesigheid (Kerr \& Vos 1993), minder werkstres (Norris, Carroll \& Cochrane 1990), laer gesondheidsorgkoste (Arena et al. 2013) en gunstige gevolge vir die maatskappy, soos 'n daling in werknemeromset (Cox, Shephard \& Corey 1981). Daarteenoor het 'n opname deur Proper et al. (2002) getoon dat bewyse vir die bogenoemde werkverwante uitkomste beperk is, nie afdoende is nie of nie bestaan nie, wat dus die doeltreffendheid van fisieke aktiwiteitsprogramme met betrekking tot genoemde uitkomste betwis. Hierdie weerspreking gee 'n aanduiding dat verdere ondersoek op dié navorsingsgebied nodig is.

\section{Gevolgtrekking}

Hierdie evaluering van welstand in die werkplek het dit moontlik gemaak om die areas van welstand te identifiseer wat ingryping nodig het. Die uitvoering van dié evaluering het getoon dat die werkplek die ideale plek vir 'n fisieke welstandprogram is, aangesien 'n groot deel van die bevolking deur hul betrokkenheid in die formele werksektor geteiken kan word. Die verbetering van die werknemer se welstandeienskappe kan dus lei tot produktiwiteit, doeltreffendheid, gehalte van werklewe en die balans tussen tuiste en werkplek (Mostert et al. 2008; Wright \& Huang 2012), en die resultate van dié studie blyk die stelling te staaf. Welstandprogramme wat fisieke aktiwiteit beklemtoon, blyk suksesvol te wees in hoë-inkomstelande, met bewys van ekonomiese voordele en opbrengs op belegging (Aldana \& Pronk 2001; Suhrcke et al. 2005), 'n feit wat weereens deur hierdie studie beaam word; daar word aangevoer dat sulke welstandprogramme ook 'n positiewe uitwerking op die Suid-Afrikaanse werkmag sal hê. Verder, met die toenemende las van nie-oordraagbare siektes in Suid-Afrika is dit gebiedend noodsaaklik dat die fokus van welstandprogramme geplaas moet word op die voorkoming van siekte, eerder as behandeling en voorkoming van komplikasies.

Verder steun die studie die opinie dat die enigste manier om wedersyds voordelige uitkomste vir die organisasie en die werknemer te kry, insluitend die vermindering van mediese koste en die bevordering van werknemers se moraal, is die integrasie van welstandsorginisiatiewe in holistiese werkwelstandprogramme. Die vermindering en voorkoming van swak gesondheid, siektes en afwesigheid in die werkplek, asook die bevordering van die gesondheid van die werknemers is sleuteluitsette in hierdie proses. Effektiewe werkwelstandprogramme moet dus voortaan fokus op die implementering van 'n veelsydige ontwikkelingsproses wat direk verband hou met die maatskappy se uitkomste.

\section{Beperkings van die studie}

Die navorsers het bevind dat die bewysmateriaal in die Suid-Afrikaanse konteks gering is, en dat die meeste studies in hoë-inkomstelande gedoen is. Dit bring mee dat dit moeilik is om bevindings op die Suid-Afrikaanse bevolking en kultuur toe te pas. Gevolglik word hierdie studie as 'n loodsstudie beskou vir verdere navorsing op dié gebied in Suid-Afrika.

Verskeie welstandprogramme wat ondersoek is, het nie 'n fisieke aktiwiteitskomponent ingesluit nie, of het uit verskeie variasies bestaan. Dit het die evaluasie van welstand in ' $n$ holistiese sin beperk.

\section{Erkenning}

Die outeurs bedank die Departement Fisiologie, Universiteit van Pretoria en Neuro-Link vir bydrae tot hierdie navorsingsprojek.

\section{Mededingende belange}

Die outeurs verklaar hiermee dat hulle geen finansiële of persoonlike verbintenis het met enige party wat hulle nadelig of voordelig kon beïnvloed het in die skryf van hierdie artikel nie.

\section{Outeursbydrae}

Die aard van die bydraes van elke outeur genoem op die lys is kortliks meer of minder soos volg opgesom: P.d.T (Universiteit van Pretoria) projekleier; P.d.T. (Universiteit van Pretoria) en E.N. (Universiteit van Pretoria) wesenlike intellektuele bydraes aan die projek en aansienlike bydraes tot konseptualisering en ontwerp, interpretasie van data, finale goedkeuring; L-A.N. (Universiteit van Pretoria) voorbereiding van die manuskrip; E.N. (Universiteit van Pretoria) redigering en finale voorbereiding van die manuskrip; R.F. (Universiteit van Pretoria), A.S. (Universiteit van Pretoria), Y.H. (Universiteit van Pretoria), A.v.S. (Universiteit van Pretoria), R.B. (Universiteit van Pretoria), J.T. (Universiteit van Pretoria), S.A. (Universiteit van Pretoria) hersiening, formattering en bydraes tot konseptualisering en ontwerp; M.K. (Universiteit van Pretoria) verkryging, analise en interpretasie van data.

\section{Literatuurverwysings}

Adams, T., Bezner, J. \& Steinhardt, M., 1997, 'The conceptualization and measurement of perceived wellness: Integrating balance across and within dimensions', American Journal of Health Promotion 11(3), 208-218. http://dx.doi.org/10.4278/08901171-11.3.208

Aghamohamadi, D., Eidy, M., Pourfathi, H., Hoseinzadeh, H., Sharabiani, B.A. \& Gorman, J.M., 2010, 'Comparison of Cardiac Stress Index with Rate Pressure Product in trans-abdominal prostatectomy', Journal of Cardiovascular and Thoracic Research 2(1), 35-38. 
Aldana, S.G. \& Pronk, N.P., 2001, 'Health promotion programs, modifiable health risks, and employee absenteeism', Journal of Occupational and Environmental Medicine 43(10), 36-46.

Al-naddaf, A. \& Dabayebeh, I., 2007, 'The effect of high intensity and low intensity exercises on body fat and weight reduction', Dirasat: Educational Sciences 34(2), 429-441.

American College of Sports Medicine, 2010, American College of Sports Medicine's guidelines for exercise testing and prescription, Wolters Kluwer Health/Lippincott Williams \& Wilkins, Baltimore, MD.

Arena, R., Guazzi, M., Briggs, P.D., Cahalin, L.P., Myers, J., Kaminsky, L.A. et al., 2013, 'Promoting health and wellness in the workplace: A unique opportunity to establish primary and extended secondary cardiovascular risk reduction programs', Mayo Clinic proceedings 88(6), 605-617. http://dx.doi.org/10.1016/j. mayocp.2013.03.002

Beam, W. \& Adams, G., 2010, Exercise physiology laboratory manual, McGraw-Hill Companies Incorporated, New York.

Birdee, G.S., Byrne, D.W., McGown, P.W., Rothman, R.L., Rolando, L.A., Holmes, M.C. et al., 2013, 'Relationship between physical inactivity and health characteristics among participants in an employee-wellness program', Journal of Occupationa and Environmental Medicine 55(5), 514-519. http://dx.doi.org/10.1097/ JOM.0b013e31827f37d7

Blair, S.N., Cheng, Y. \& Scott Holder, J., 2001, 'Is physical activity or physical fitness more important in defining health benefits?', Medicine and Science in Sports and Exercise 33(6), S379-S399. http://dx.doi.org/10.1097/00005768-20010600100007

Booth, F.W., Chakravarthy, M.V. \& Spangenburg, E.E., 2002, 'Exercise and gene expression: Physiological regulation of the human genome through physical
activity', Journal of Physiology 543(2), 399-411. http://dx.doi.org/10.1113/ activity', Journal of
jphysiol.2002.019265

Caldwell, M. \& Huitt, W., 2004, 'An overview of physical development', Educational Psychology Interactive, n.p.

Centers for Disease Control and Prevention (CDC), 2011, 'Vital signs: prevalence, treatment, and control of hypertension - United States', 1999-2002; 2005-2008, Morbidity and Mortality Weekly Report 60(4), 103-108.

Christensen, J.R., Faber, A., Ekner, D., Overgaard, K., Holtermann, A. \& Søgaard, K. 2011, 'Diet, physical exercise and cognitive behavioral training as a combined workplace-based intervention to reduce body weight and increase physica capacity in health care workers: A randomized controlled trial', BMC Public Health 11, 671-681. http://dx.doi.org/10.1186/1471-2458-11-671

Cox, M., Shephard, J. \& Corey, P., 1981, 'Influence of an employee fitness programme upon fitness, productivity and absenteeism', Ergonomics 24(10), 795-806. http:// dx.doi.org/10.1080/00140138108924900

Edlin, G., Golanty, E. \& Brown, K.M., 2000, Essentials for Health and Wellness, Jones \& Bartlett Learning, Burlington, MA.

Els, C., Pienaar, J. \& Sieberhagen, C., 2011, 'Management of employee wellness in South Africa: Employer, service provider and union perspectives', SA Journal of Human Resource Management 9(1), 1-14.

Energy-Lab Technologies GmbH, 2010, Vicardio, the Electric Cardio Portrait, viewed 20 June 2014, from http://www.vicardio.de/en/bibliothek/fallbeispiel_detail. php?id=3

Energy-Lab Technologies GmbH, Viport, viewed 20 June 2014, from http://www. viport.de/viport/c_14.php\#messwerte

Gerber, L.M. \& Crews, D.E., 1999, 'Evolutionary perspectives on chronic degenerative diseases', in W.R. Trevathan, E.O. Smith \& J.J. McKenna (eds.), Evolutionary Medicine, Oxford University Press, New York, Oxford, pp. 443-469.

Hurley, J.S. \& Schlaadt, R.G., 1992, The wellness life-style, Dushkin Publishing Group, Guildford.

Jeukendrup, A. \& Gleeson, M., 2009, Sport nutrition: An introduction to energy production and performance, 2 nd edn., Human Kinetics Publishers, Champaign, II.

Kerr, J.H. \& Vos, M.C.H., 1993, 'Employee fitness programmes, absenteeism and general well-being', Work and Stress 7(2), 179-190. http://dx.doi. org/10.1080/02678379308257059
Laaksonen, M., Práttalä, R. \& Karisto, A., 2001, 'Patterns of unhealthy behaviour in Finland', European Journal of Public Health 11(3), 294-300. http://dx.doi. org/10.1093/eurpub/11.3.294

Labuschagne, R., Strydom, G.L. \& Wilders, C.J., 2011, 'Die invloed van deelname aan fisieke aktiwiteit tydens vrye tyd op die koronêre risiko-, lewenstyl- en gesondheidstatus-indeks van werknemers by'n finansiële instelling' South African Journal for Research in Sport, Physical Education and Recreation 33(2), 81-93.

Mackenzie, B., 2005, 101 performance evaluation tests, Electric Word plc, London.

Masley, S.C., Weaver, W., Peri, G. \& Phillips, S.E., 2008, 'Efficacy of lifestyle changes in modifying practical markers of wellness and aging', Alternative Therapies in Health and Medicine 14(2), 24-29.

McArdle, W.D., Katch, F.I. \& Katch, V.L., 2010, Exercise physiology: Nutrition, energy, and human performance, Wolters Kluwer Health/Lippincott Williams \& Wilkins, Philadelphia, PA.

Mostert, F.F., Rothmann, S., Mostert, K. \& Nell, K., 2008, 'Outcomes of occupational stress in a higher education institution', Southern African Business Review 12(3), 102-127.

Myers, J.E. \& Sweeney, T.J., 2005, 'Epilogue: Future directions in wellness counseling', Counseling for wellness: Theory, research, and practice, 273.

Norman, R., Bradshaw, D., Schneider, M., Joubert, J., Groenewald, P., Lewin, S. et al., 2007, 'A comparative risk assessment for South Africa in 2000: Towards promoting health and preventing disease', South African Medical Journal 97(8), 637-641.

Norris, R., Carroll, D. \& Cochrane, R., 1990, 'The effects of aerobic and anaerobic training on fitness, blood pressure, and psychological stress and wellbeing', Journal of Psychosomatic Research 34(4), 367-375. http://dx.doi. org/10.1016/0022-3999(90)90060-H

Prentice, W.E., 1999, Fitness and wellness for life, WCB/McGraw-Hill, Boston.

Proper, K.I., Staal, B.J., Hildebrandt, V.H., Van der Beek, A.J. \& Van Mechelen, W., 2002, 'Effectiveness of physical activity programs at worksites with respect to workrelated outcomes', Scandinavian Journal of Work, Environment and Health 28(2), 75-84. http://dx.doi.org/10.5271/sjweh.651

Rongen, A Robroek, S.J.W. Van Ginkel, W. Lindeboom, D. Altink, B. \& Burdorf, A 2014 , 'Barriers and facilitators for participation in health promotion programs among employees: A six-month follow-up study', Acta Veterinaria Scandinavica among employer

Seggie, J., 2012, 'Alcohol and South Africa's youth', South African Medical Journal 102(7), 587

Shain, M. \& Kramer, D.M., 2004, 'Health promotion in the workplace: Framing the concept: reviewing the evidence', Occupational and Environmental Medicine 61(7), 643-648. http://dx.doi.org/10.1136/oem.2004.013193

Suhrcke, M., McKee, M., Arce, R.S., Tsolova, S. \& Mortensen, J., 2005, 'The contribution of health to the economy in the European Union', Health \& Consumer Protection Directorate-General, European Communities, viewed n.d., from http://europa.eu.int

Thomas, E.L., Saeed, N., Hajnal, J.V., Brynes, A., Goldstone, A.P., Frost, G. et al., 1998 'Magnetic resonance imaging of total body fat', Journal of Applied Physiology 85(5), 1778-1785.

Van Zyl, S., Van der Merwe, L.J., Walsh, C.M., Groenewald, A.J. \& Van Rooyen, F.C., 2012, 'Risk-factor profiles for chronic diseases of lifestyle and metabolic syndrome in an urban and rural setting in South Africa', African Journal of Primary Health Care and Family Medicine 4(1), 1-10. http://dx.doi.org/10.4102/phcfm.v4i1.346

Westerterp, K.R., 2010, 'Physical activity, food intake, and body weight regulation: Insights from doubly labeled water studies', Nutrition Reviews 68(3), 148-154. http://dx.doi.org/10.1111/j.1753-4887.2010.00270.x

Wierenga, D., Engbers, L.H., Van Empelen, P., Duijts, S., Hildebrandt, V.H. \& Van Mechelen, W., 2013, 'What is actually measured in process evaluations for
worksite health promotion programs: A systematic review', BMC Public Health worksite health promotion programs: A systematic review', BMC
13(1), 1190-1205. http://dx.doi.org/10.1186/1471-2458-13-1190

Witmer, J.M. \& Sweeney, T.J., 1992, 'A holistic model for wellness and prevention over the life span', Journal of Counseling \& Development 71(2), 140-148. http://dx.doi. org/10.1002/j.1556-6676.1992.tb02189.x

Wright, T.A. \& Huang, C., 2012, 'The many benefits of employee well-being in organizational research', Journal of Organizational Behavior 33, 1188-1192. http://dx.doi.org/10.1002/job.1828 